\title{
PSP detoxification kinetics in the mussel Mytilus galloprovincialis. One- and two- compartment models and the effect of some environmental variables
}

\author{
J. Blanco ${ }^{1, *}$, A. Moroño ${ }^{1}$, J. Franco ${ }^{2, * *}$, M. I. Reyero ${ }^{3}$ \\ ${ }^{1}$ Centro de Investigacións Mariñas, Consellería de Pesca, Xunta de Galicia, Aptdo. 13, E-36620 Vilanova de Arousa, Spain \\ ${ }^{2}$ Instituto de Investigaciones Marinas, Eduardo Cabello, 6, E-36208 Vigo, Spain \\ ${ }^{3}$ Centro Costero de Vigo, Instituto Español de Oceanografía, Aptdo 1552, E-36280 Vigo, Spain
}

\begin{abstract}
Paralytic shellfish poisoning (PSP) toxins are accumulated by bivalves during toxic plankton blooms. In these bivalves the toxins are distributed into different body tissues which have varying affinities for them, and later these toxins are transferred by the bivalves to other trophic levels After the disappearance of the toxic cells, shellfish remain toxic for a variable period of time, depending on the detoxification kinetics. We studied these kinetics in mussels Mytilus galloprovincialis previously exposed to a bloom of the PSP producing dinoflagellate Gymnodinium catenatum. The toxin profile observed in the mussels was very similar to that of $G$. catenatum, showing that toxin transformations (chemical or enzymatic) had little or no importance in this case. The detoxification rates at all the sampling points decreased progressively from ca 0.25 to $0 \mathrm{~d}^{-1}$ following an inverse hyperboliclike curve. These rates were related to different degrees to the environmental factors studied (salinity, temperature, and light transmission as a measure of seston volume, and in vivo fluorescence as a measure of phytoplankton concentration) and to fresh body weight during each sampling period (estimated by multiple regression). In general, detoxification rates became increasingly independent of the variables cited as the experiment progressed. One- and 2-compartment detoxification models, both with 2 variants (with fixed and variable detoxification rates depending on the environmental variables and body weight), were used to describe the detoxification kinetics observed. Neither of the 2 variants of the 1-compartment models correctly described detoxification. The 2-compartment models, on the other hand, particularly the environmentally controlled variant, fit the observed detoxification kinetics very well. There was only a slight difference between these last 2 models, which would suggest that the actual effect of the environmental variables considered in the detoxification process is unimportant.
\end{abstract}

KEY WORDS: PSP Detoxification kinetics Salinity - Temperature - Seston volume - Phytoplankton concentration Body weight. Mussel Gymnodinium catenatum

\section{INTRODUCTION}

The incidence of phycotoxins is having a very adverse effect upon bivalve culture all over the world (Shumway et al. 1988, Shumway 1990, Shumway \& Cembella 1993). Paralytic shellfish poisoning (PSP) toxins have a prominent place among these com-

-E-mail: jblanco@cima.org

-Present address: Centro Costero de Vigo, Instituto Español de Oceanografía Aptdo 1552, E-36280 Vigo, Spain pounds. Their high toxic power together with the bivalve's ability to accumulate them make it possible for these organisms to attain concentrations that can seriously threaten the health of the consumer. In order to avoid this risk many countries have implemented monitoring programmes which include early detection of toxic episodes and diverse mechanisms to prevent contaminated products from reaching the market. These mechanisms, mostly of collecting and marketing closures, result in immediate financial losses and cause major disruptions in the culture cycle. 
The development of dynamic models linking toxic cell concentration and environmental variables with toxin accumulation in the bivalve body could provide a very valuable tool for predicting the timing and duration of the closure periods and for optimizing culture conditions. Thus, such models may partially mitigate the economic losses and increase the safety levels of the monitoring programmes. Notwithstanding, there have been very few attempts in this direction: see Silvert \& Subba Rao (1992), Blanco et al. (1995) and Silvert \& Cembella (1995). Only the last-mentioned study deals with PSP toxins and only the first one addresses an environmental condition (temperature).

The strong dependence of bivalve feeding behaviour and metabolism on the environmental conditions has been reported in a number of studies (Bayne et al. 1976a, b, Hawkins \& Bayne 1992); hence toxin assimilation and detoxification should also be affected by environmental conditions. There is evidence, from field studies, that this effect actually exists (Sampayo et al. 1990, Shumway 1990, Marcaillou-LeBaut et al. 1993) but it may be masked by the different behaviour of toxins in the different body tissues. Blogoslawski \& Stewart (1978), Cembella et al. (1993), and Bricelj \& Cembella (1995) have shown that the digestive gland, gill, muscle, mantle, gonad and kidney differ substantially in their ability to accumulate toxins. Cembella et al. (1993) reported that in Placopecten magellanicus and Spisula solidissima this difference in accumulation is due to clearly differentiated intoxication and detoxification kinetics. This type of tissue-specific kinetics suggests that when modelling changes in global toxin concentration in bivalves it is necessary to include as many compartments as tissues. The models derived taking these considerations into account would include an excessive number of variables and rates, which may be attributed to 2 additional aspects: (1) toxins are not only eliminated from tissues but also transferred between them, and (2) the environmental variables probably affect the detoxification rates and transfer rates. Consequently, these models would be impractically complex. Nevertheless, in some species in which body mass or affinity for toxins is clearly biassed towards one or a few tissues, or in which several compartments have similar kinetics, the aforementioned complex models can be adequately replaced by others containing only 1 or 2 compartments.

In this study we examine the adequacy of both 1 and 2-compartment models to describe the detoxification kinetics of PSP toxins in mussels Mytilus galloprovincialis previously exposed to a Gymnodinium catenatum bloom, as well as the effects of temperature, salinity, seston volume, phytoplankton concentration and body weight on the detoxification rates obtained.

\section{MATERIAL AND METHODS}

Sampling and analysis. In November 1994, mussels intoxicated by a bloom of Gymnodinium catenatum, which had started 12 d earlier and persisted on the sampling date, were collected from Bueu (Ría de Pontevedra, Spain), then placed into $1 \mathrm{~cm}$ mesh-size culture baskets, at a density of 60 mussels per basket, and transferred to the Ría de Arousa, where they were distributed among 4 rafts (Fig. 1 ) at 2 depths ( 3 and $8 \mathrm{~m}$ ). The sampling points were chosen from the 10 points at which the Centro para o Control da Calidade do Medio Mariño (Consellería de Pesca, Xunta de Galicia, Spain) weekly monitors the principal physical, chemical, and biological oceanographic variables. These points and depths were chosen for the following reasons: (1) they have a low probability of reintoxication; and (2) they constitute the set of stations and depths that had, during November and December of the 3 previous years, the minimal covariation of salinity, temperature, fluorescence and light transmission. The probability of reintoxication was quantified using data on the concentration of $G$. catenatum, and it was considered absolutely indispensable to study the detoxification kinetics without the strong interferences that reintoxications may introduce. It was also considered highly advisable to minimize the collinearity among the environmental variables, and thus provide good estimations of their individual effect on the detoxification rate (which is increasingly inaccurate as collinearity increases). This was accomplished by means of the principal component analysis (PCA) of the above-mentioned data.

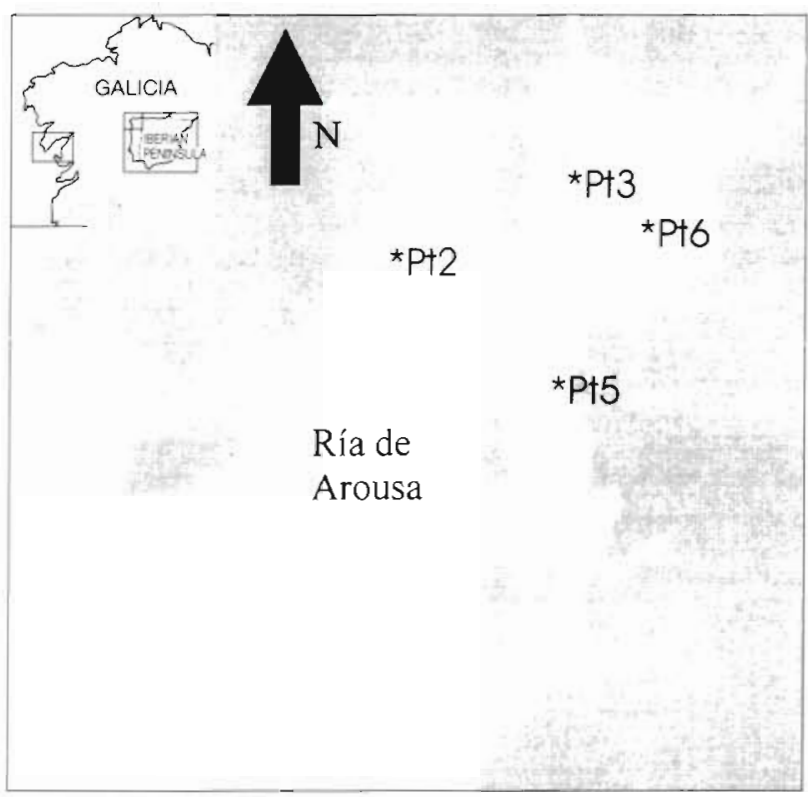

Fig. 1. Geographic location of the 4 sampling points ( $\mathrm{Pt}$ ) in Spain 
Over a $70 \mathrm{~d}$ period, samples of 20 mussels were collected from each point and depth, first on a weekly basis and later at longer intervals as detoxification slowed up.

Mussels were measured, weighed and all the tissues homogenized. The toxins contained in a $10 \mathrm{~g}$ aliquot were extracted by mixing the aliquot vigourously with $10 \mathrm{ml}$ of $\mathrm{HCl} 0.1 \mathrm{~N}$; the mixture was centrifuged $(1000 \times g)$, recovering the supernatant. The 2 previous steps were repeated twice with $5 \mathrm{ml}$ of $\mathrm{HCl}$. Finally, the total supernatant was brought to $20 \mathrm{ml}$ and the $\mathrm{pH}$ adjusted with $\mathrm{HCl}$ to $3-4$.

Toxin analyses were carried out by HPLC following the procedure proposed by Franco \& Fernández (1993). The identification and quantification of $C 1$ and C2 toxins were carried out by means of hydrolysis and the subsequent determination of Gonyautoxin 2 (GTX2) and Gonyautoxin 3 (GTX3). The standards of these 2 toxins were provided by the National Research Council of Canada. The quantification of decarbamoylSaxitoxin (dcSTX) was made with standards provided by the Bureau Communitaire de Reference (European Union).

Temperature, salinity, light transmission and in vivo fluorescence of chlorophyll a were sampled twice a week during most of the experiment, with a Sea-

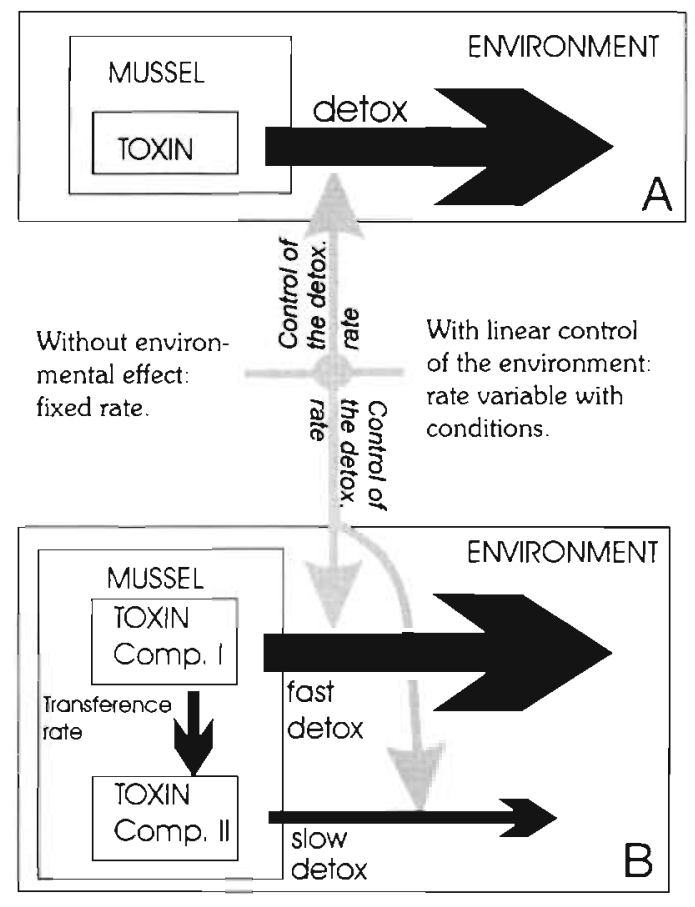

Fig. 2. Conceptual representation of the (A) 1-compartment and (B) 2-compartment models. The solid arrows represent toxin flows and grey ones represent the environmental control of the rates
Bird 25 conductivity/temperature/depth profiler (CTD) equipped with a Seatech Fluorometer and Transmissometer.

The effects of the environmental conditions and wet body weight on the detoxification rate was quantified by multiple regression with backwards elimination using the Minitab 10xtra Statistical Package. A PCA was also carried out with the same package in order to detect collinearity between the predictor variables in the regression. Three types of estimations based on the regression analysis were made: (1) individual estimations, including each detoxification period; (2) global estimation, including all detoxification data obtained during the experiment; and (3) partial estimations, including the first (fast) detoxification period to estimate the detoxification rate of the first compartment and the last 3 to estimate the rate of the second compartment

Models. Two models were used in relation to detoxification: 1- and 2-compartment (Fig. 2). The 1compartment model assumed that the entire toxicity in the mussel body is not affected or is affected in the same way in all body tissues by the environmental variables and body weight. The relationship, therefore, was assumed to be constant or linear, thus:

$$
\begin{aligned}
& D T R=K(\text { fixed rate model }) \\
& \text { or } \\
& D T R=a+b \times \text { Salinity }+c \times \text { Temperature }+d \times \\
& \text { Fluorescence }+e \times \text { Transmittance }+f \times \\
& \text { Body weight (variable rate model) } \\
& \frac{\mathrm{d}(T O X)}{\mathrm{d} t}=-D T R \times T O X
\end{aligned}
$$

where $K=$ constant, $T O X=$ total toxin concentration, $D T R=$ detoxification rate and $a$ to $f$ are constants.

The 2-compartment model also assumed that detoxification rates were constant or linearly related to the environmental conditions and body weight, but different depending on the compartment. It was also assumed that a toxin flow from compartment 1 (rapid detoxification) to compartment 2 (slow detoxification) existed.

$$
\begin{aligned}
& D T R_{1}=K_{1} \text { (fixed rate model) } \\
& \text { or } \\
& D T R_{1}=a_{1}+b_{1} \times \text { Salinity }+c_{1} \times \text { Temperature }+d_{1} \times \\
& \text { Fluorescence }+e_{1} \times \text { Transmittance }+f_{1} \times \\
& \text { Body weight (variable rate model) } \\
& D T R_{2}=K_{2} \text { (fixed rate model) } \\
& \text { or } \\
& D T R_{2}=a_{2}+b_{2} \times \text { Salinity }+c_{2} \times \text { Temperature }+d_{2} \times \\
& \text { Fluorescence }+e_{2} \times \text { Transmittance }+f_{2} \times \\
& \text { Body weight (variable rate model) }
\end{aligned}
$$


and

$$
\begin{aligned}
& \frac{\mathrm{d}\left(T O X_{1}\right)}{\mathrm{d} t}=-D T R_{1} \times T^{\prime} X_{1}-C R \times T O X_{1} \\
& \frac{\mathrm{d}\left(T O X_{2}\right)}{\mathrm{d} t}=-D T R_{2} \times T O X_{2}+C R \times T O X_{1} \\
& \frac{\mathrm{d}(T O X)}{\mathrm{d} t}=\frac{\mathrm{d}\left(T O X_{1}\right)}{\mathrm{d} t}+\frac{\mathrm{d}\left(T O X_{2}\right)}{\mathrm{d} t}
\end{aligned}
$$

where $C R$ is the transport rate from the first to the second compartment and all the remaining abbreviations are the same as in the previous model. The numerical subindices indicate the compartment.

Detoxification rates between consecutive sampling dates were computed by means of the following expression:

$$
D T R_{L k}=1-\sqrt[k-i]{\operatorname{TOX}_{k} / T O X_{i}}
$$

where $D T R_{i k}$ is the detoxification rate from Day $i$ to Day $k$ and $T O X_{i}$ and $T O X_{k}$ are the toxicities measured on the corresponding days.

\section{RESULTS}

\section{Environmental variables and body weight}

The environmental conditions and body weight changed in both time and space (Fig. 3). The temperature fluctuation throughout the period studied was $2.2^{\circ} \mathrm{C}$ (ranging from 13 to $15.2^{\circ} \mathrm{C}$ ). The experiment was carried out during a typical winter situation, with thermal inversion, and therefore with higher temperatures at the bottom than at the surface. Salinity was directly related to temperature and also exhibited the lowest values at the surface. It ranged from 27.3 to $34.4 \%$ over time. The range of the spatial change of this variable was lower than in temporal variation, but in all cases it was greater than $1 \%$. Both spatial and temporal differences were smaller at the bottom that at the surface. Fluorescence and light transmission also showed great spatial and temporal differences. Fluorescence varied during the experiment from less than 0.08 relative units (r.u.) to 0.63 r.u. (roughly equivalent to $0.3-1.9 \mu \mathrm{g}$ of chlorophyll a $\mathrm{l}^{-1}$ ), having a maximum range among all the sampling points and depths (on the same day) of ca 0.45 r.u. Light transmission also varied greatly during the experiment (from 60 to $90 \%$ ), but its maximum range among the sampling points and depths (on the same day) was the smallest (in relative terms) of the variables considered $(12 \%)$. Body weight also exhibited great differences and a slightly ascending general trend. Only in 2 out of the 8 sampling points was the final body weight lower than the initial weight. Moreover, these 2 points are also the ones with the greatest fluctuations in salinity during the period studied.

\section{Toxin profile}

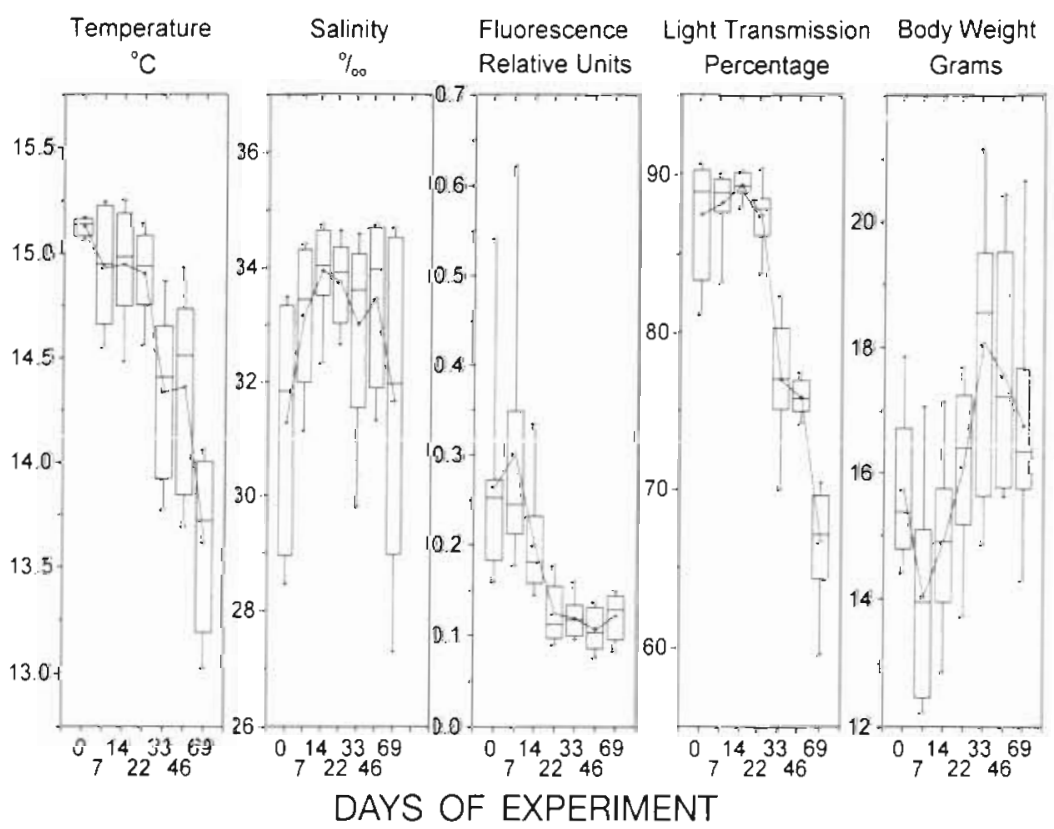

Fig. 3. Evolution of the environmental variables and mussel fresh body weight during the experiment. Fluorescence is expressed in relative units and light transmission as percentage
The toxin profile of the mussels found in this study was characterized by high relative proportions of $\mathrm{C} 1, \mathrm{C} 2$ and decarbamoylSaxitoxin (dcSTX) as well as by the presence of $\mathrm{C} 3, \mathrm{C} 4, \mathrm{GTX} 6$, GTX5, GTX2+3 in small amounts and traces of Neosaxitoxin (NeoSTX). We have considered only the first 3 toxins cited as they represent most of the toxicity in the mussels and, in addition, we have reliable standards for these toxins. Throughout the experiment no apparent change in the relative contribution of these 3 toxins in relation to the remaining ones was observed by the visual examination of the chromatograms.

\section{Detoxification rates}

Detoxification rates varied between 0.27 and $-0.08 \mathrm{~d}^{-1}$ (both values recorded at sampling point 3 at $8 \mathrm{~m}$ 


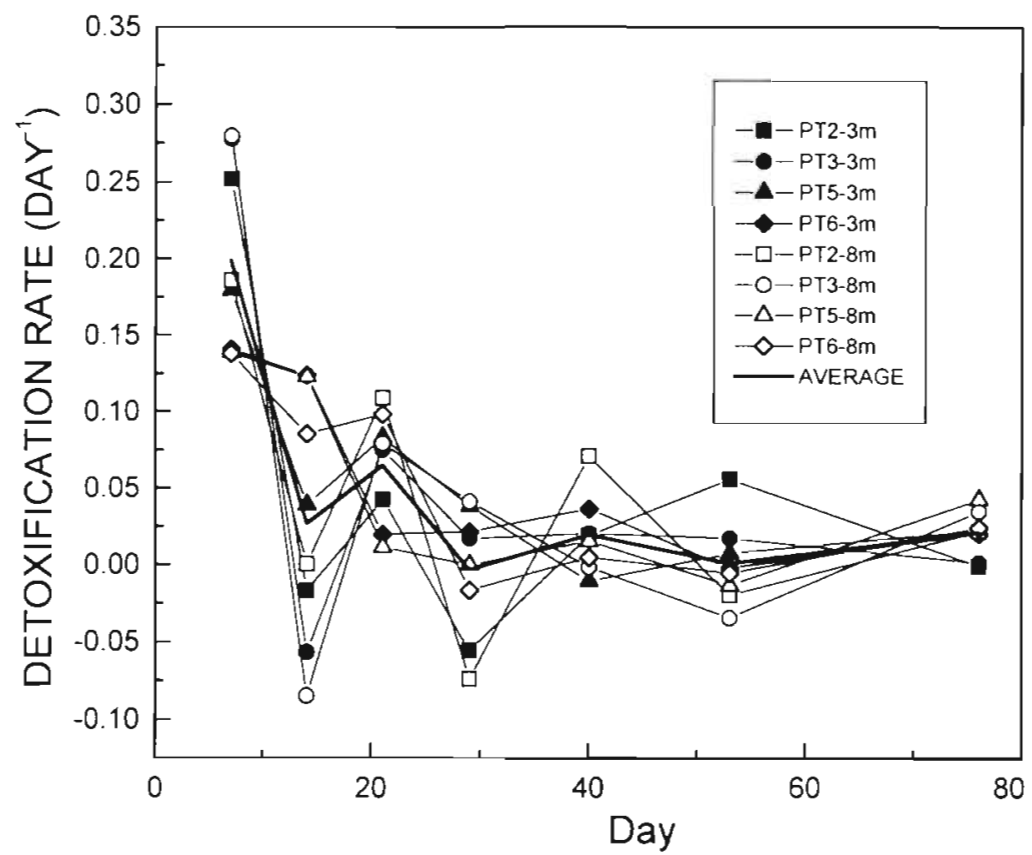

Fig. 4. Variation of the detoxification rates during the experiment at the different depths and sampling points (Pt) depth). Average values of the 8 sampling points ranged approximately from 0.20 to $0 \mathrm{~d}^{-1}$. They showed a decreasing trend during the first $3 \mathrm{wk}$ of the experiment and then stabilized at low values (Fig. 4).

\section{Regression analysis of the detoxification rates}

When the detoxification rate was adjusted by multiple regression with the 5 variables considered in this study, both the significance levels and the relevant variables (those included in the final step of the backwards elimination multiple regression) showed differences on the different sampling dates (corresponding to the detoxification periods). In the second, fourth and fifth detoxification periods the regression was not sig-
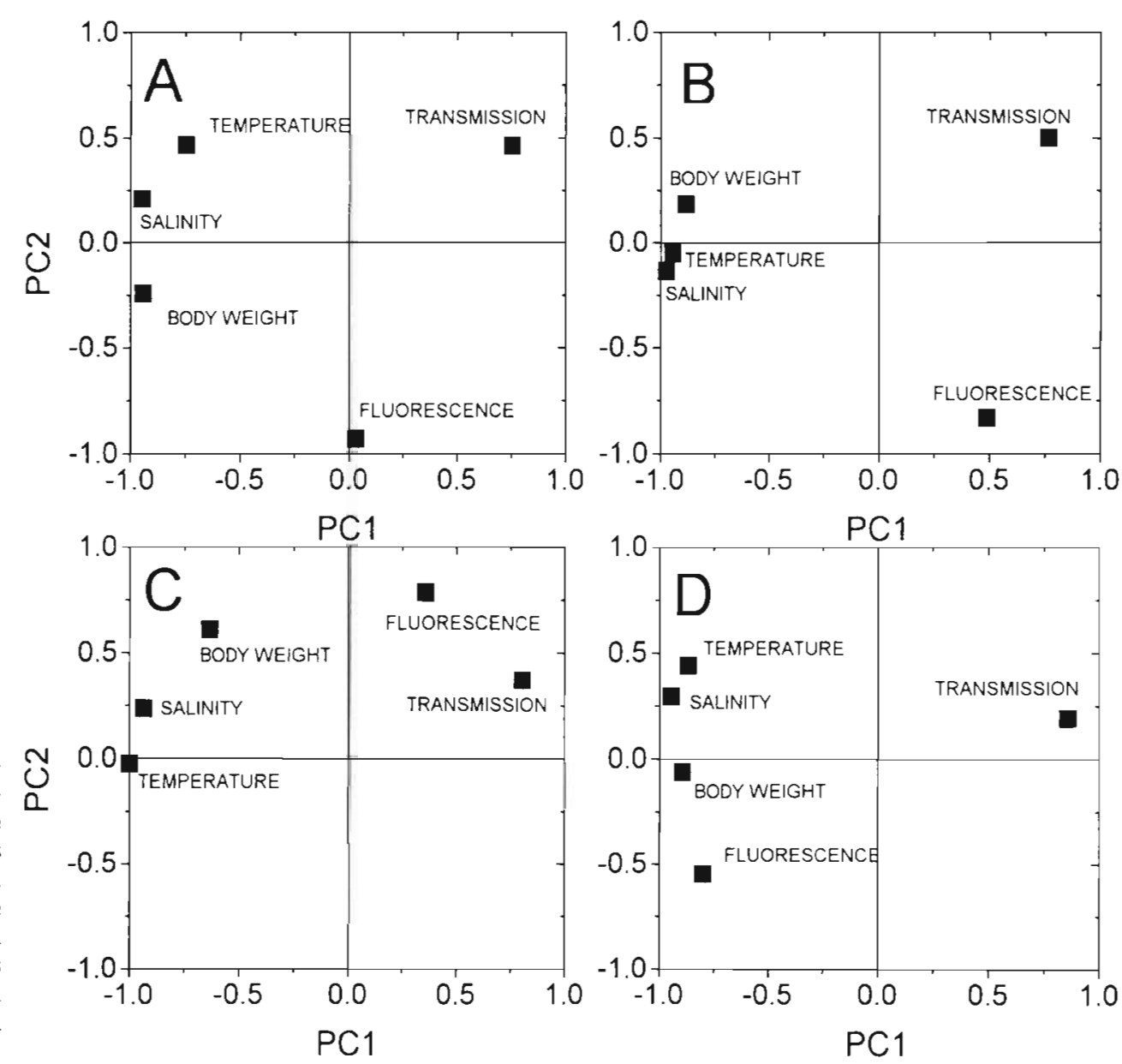

Fig. 5. Loadings of the environmental variables and mussel fresh body weight on the first 2 principal components (PC1 and PC2) extracted from the data corresponding to the (A) first (Days 0 to 7 ), (B) third Days 14 to 21), (C) sixth (Days 40 to 53), and (D) seventh (Days 53 to 76 ) detoxification periods 
nificant. In the first period, light transmission, salinity and body weight were the relevant variables, the first variable having a negative coefficient and the last 2 being positive. In this case, the regression fitted very well, which would explain the highest percentage of variance found in the 7 detoxification periods $(92.4 \%)$. PCA showed that salinity, body weight and, to a lesser extent, temperature, were related to PC1 (Fig. 5A), making it impossible to distinguish the individual participation of each variable. In the third period, only body weight had a significant effect, but opposite to that which it had in the first period. As in the previous case, it was strongly related to PC1 (Fig. 5B), to which salinity and temperature were also highly related. In the sixth period, temperature had a negative effect, but the percentage of variance explained was only $51 \%$ of the total variance. In this case, temperature was closely related to salinity $(r=0.93)$ and therefore the effects of these two cannot be distinguished (Fig. $5 \mathrm{C}$ ). In the seventh period the variance explained $(86 \%)$ was the second highest (after the first period) and temperature and body weight were the relevant variables, both having positive coefficients. In this case all variables had high loadings on PC1, so it is again impossible to quantify their individual effect (Fig. 5D).

In addition to the previous 'per sample period' estimations, the integration of the environmental variables and body weight into the proposed models required some model-specific regression analyses. Thus, the 1 compartment model assumes that all the toxins in the mussel body behave in the same way at any given time and, consequently, a unique regression (including all the data in the experiment) between the detoxification rate and the same predictor variables as in the previous cases should be used. In this regression, only temperature and salinity were found to make a relevant contribution, accounting for $36 \%$ of the total variance.

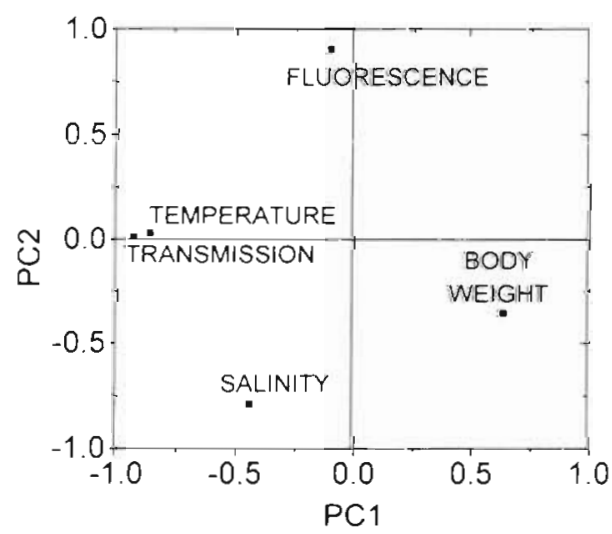

Fig. 6. Loadings of the environmental variables and mussel fresh body weight on the first 2 principal components extracted from all the data obtained in the experiment
The equation obtained was:

DTR $=-0.39-0.0229 \times$ Salinity $+0.081 \times$ Temperature

The PCA extracted 2 components, the first with high loadings of temperature and light transmission (both positive), and the second with a highly negative loading on salinity and positive in the case of fluorescence (Fig. 6). In consequence the effects of the variables of each pair cannot be individualized.

The assumption that a 2-compartment model correctly describes the detoxification kinetics implies that if the detoxification rates are affected by the environmental variables, then they might be affected differently in each compartment. In this case we assumed that the first detoxification data (from the first to the second week) represented the actual values of the first, more dynamic compartment, and from the third observation to the end, represented the values of the second compartment

During the first detoxification period, the regression equation obtained was:

$$
\begin{aligned}
D T R_{\mathrm{1}}= & 1.50+0.0829 \times \text { Salinity }-0.0567 \times \text { Trans }- \\
& \text { mittance }+0.0677 \text { Body weight }
\end{aligned}
$$

Light transmission and salinity were highly correlated during this period. The pairs salinity-temperature and light transmission-fluorescence also had high correlation coefficients.

After the third week of the experiment the detoxification rates correlated poorly with the environmental variables. Fluorescence was the only one that affected them significantly but it explained a reduced variance percentage (about $18 \%$ ). The relation is expressed as:

$$
D T R_{2}=-0.0221+0.31997 \times \text { Fluorescence }
$$

During this period, fluorescence did not correlate well with any other predictor variable and therefore no influence of these variables on the regression equation can be expected.

Fixed rate models

When a model having a unique compartment with fixed detoxification rates (not affected by environmental variables) was fitted, the actual toxicity values systematically deviated from the model (Fig. 7A). The first observation fell below the expected toxicities, while all the rest were higher than expected. Therefore, there was an obvious lack of fit due to the structure of the model rather than to error. In this case, a detoxification rate of $0.15 \mathrm{~d}^{-1}$ produced the best fit.

In a 2-compartment model with fixed detoxification rates for each compartment, it is necessary to estimate 4 parameters: the 2 detoxification rates, the net trans- 
Fig. 7. Detoxification kinetics and fitted 1-compartment models for each sampling point $(\mathrm{Pt})$. Series A shows the fitted fixed rate model (without environmental effect) and series $B$ the corresponding variable rate models (environmentally determined rates). Toxin concentration is expressed as $\mu \mathrm{g}$ of total toxins per $g$ of mussel meat

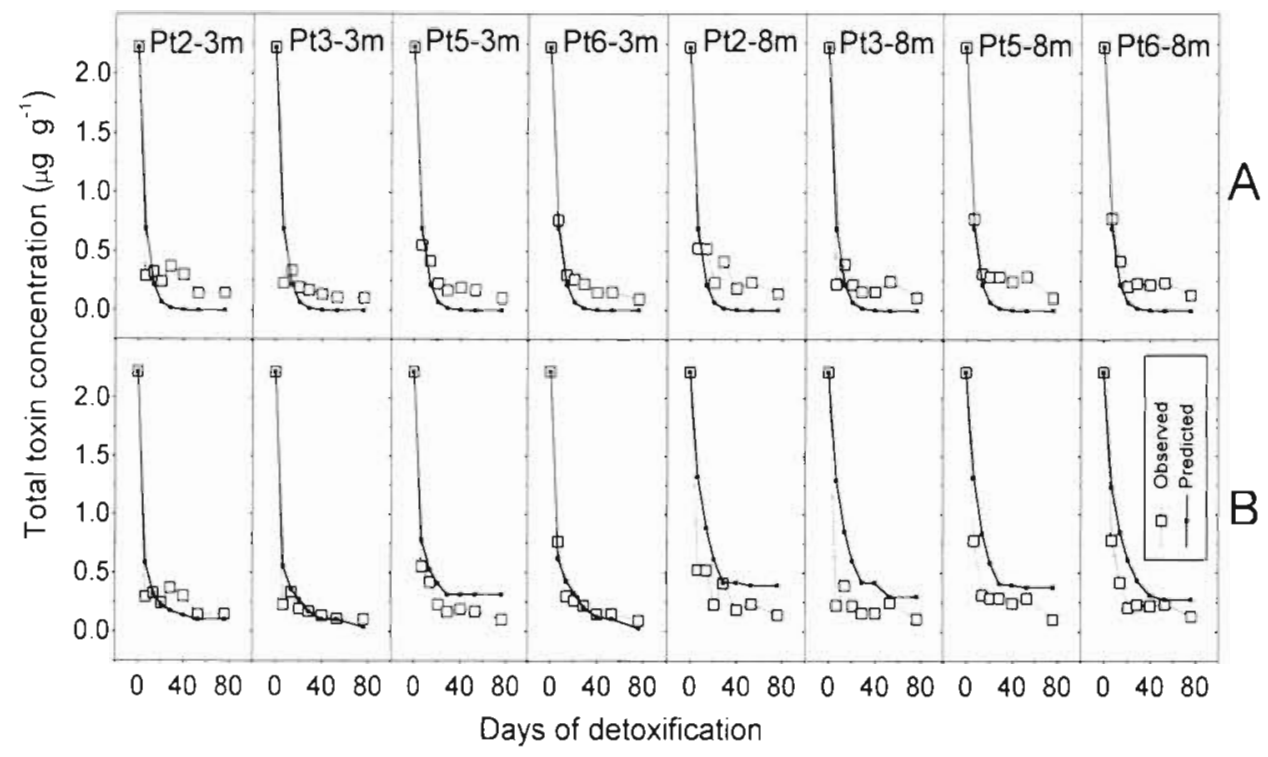

fer rate between compartments and the initial proportion of toxicity in each compartment. When this model was implemented, the predictions obtained fitted the actual data much more accurately than those obtained using the 1-compartment model (Fig. 8A). In this case, the systematic deviation disappeared; only on the second day did we observe a noticeable discrepancy at almost all of the sampling points and depths. In this case, the estimated detoxification rates were 0.21 and $0.02 \mathrm{~d}^{-1}$ for the first (Comp1) and the second (Comp2) compartments respectively. The initial proportions of the toxic pools were $93 \%$ in Comp1 and $7 \%$ in Comp 2 and the rate of change from Comp1 to Comp2 was $0.09 \mathrm{~d}^{-1}$.

\section{Variable rate models}

When the environmental variables were considered in the model (by linearly determining the detoxification rates; Fig. 2), toxicities generally had a better fit than with the corresponding (1- or 2-compartment) fixed rate models. The 1 -compartment model, in which the detoxification rates were estimated from the 5 variables studied by multiple regression, provided a better fit than its fixed rate counterpart at some of the sampling points. However, at others it was not as good (Figs. 7B \& 8B). Fitting was better at sampling points located at the surface rather than at the bottom, 0.065 $\mathrm{d}^{-1}$ and $90.8 \%$ respectively.
Fig. 8. Detoxification kinetics and fitted 2- compartment models for each sampling point (Pt). Series A shows the fitted fixed rate model (without environmental effect) and series $B$ the corresponding variable rate models (environmentally determined rates). Toxin concentration is expressed as $\mu \mathrm{g}$ of total toxins per $g$ of mussel meat

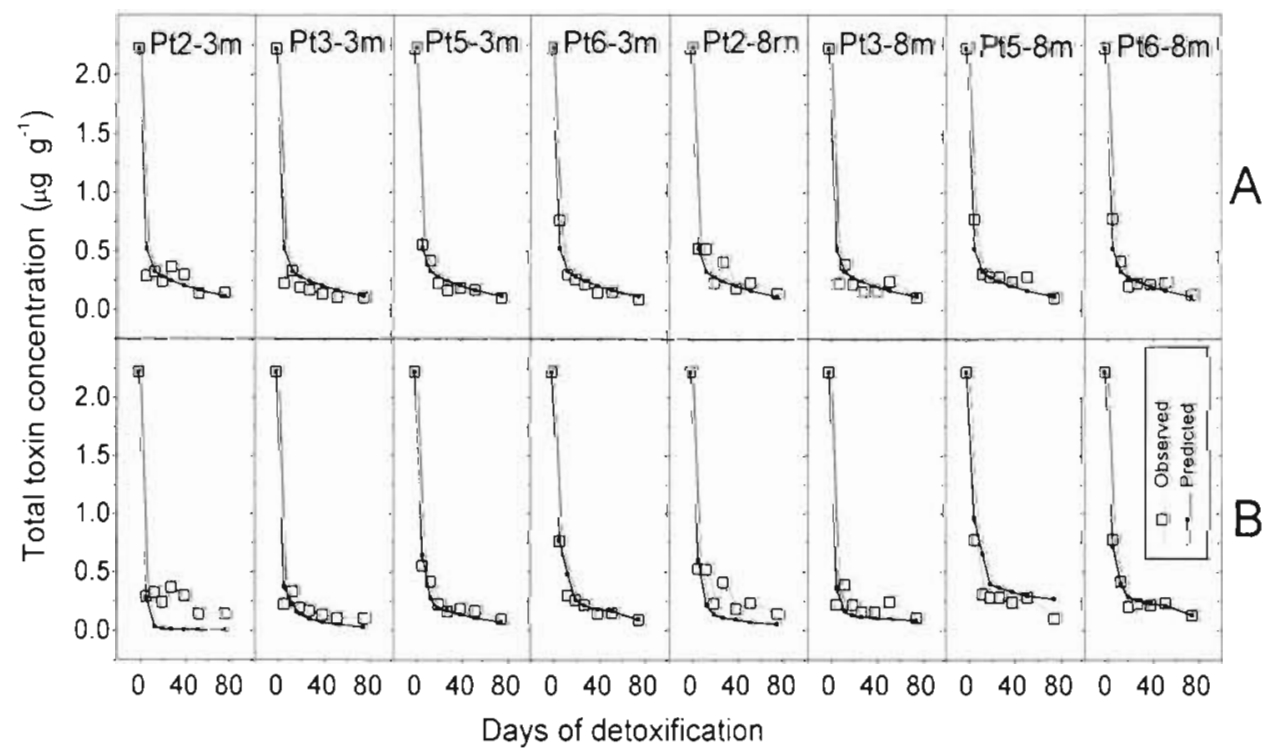




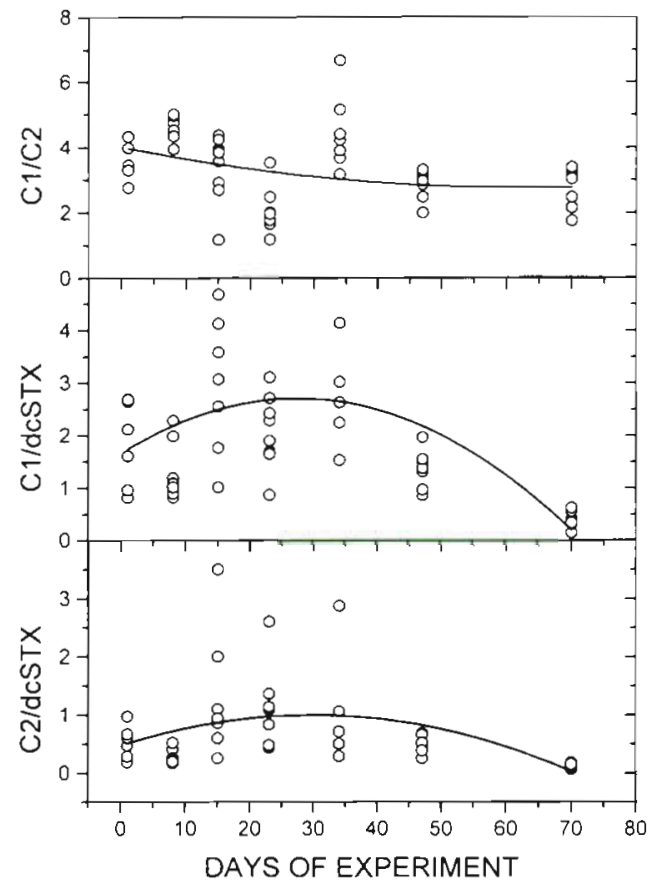

Fig. 9. Variation of the proportions between toxins during the detoxification period. Outliers are not shown

\section{Differences between toxins}

The 3 toxins under consideration did not behave in a uniform way. C1 and C2 were well correlated ( $\mathrm{r}=$ 0.767 ) but they both showed a poor correlation with dcSTX $(r=0.587$ and $r=0.318$, for $\mathrm{C} 1$ and $\mathrm{C} 2$ respectively). Correlations between their detoxification rates were lower than between concentrations. Only in the case of the $\mathrm{C} 1$ detoxification did the environmental variables account for more than $20 \%$ of the total variance $(25 \%)$. The relative contribution of each toxin to the total toxin concentration was also variable and independent of the environmental conditions and body weight, although a parabolic evolution may be observed over time in the relationship between the $2 \mathrm{C}$ toxins and dcSTX (Fig. 9).

\section{DISCUSSION}

The toxin profiles observed matched those reported for proliferations of Gymnodinium catenatum very well (Anderson et al. 1989, Franca et al. 1993, Oshima et al. 1993), which would suggest that toxins were not substantially transformed by the metabolism of the mussel.

Detoxification rates found in this study fit in the range of values obtained by other authors for PSP in mussels (Sommer \& Meyer 1937, Aatvik \& Framstad 1981, Lassus et al. 1989, Chebib et al. 1993, Silvert \&
Cembella 1995). They are also within the range corresponding to other toxins such as Domoic acid (Silvert \& Subba Rao 1992, Wolgeschaffen et al. 1992) or diarrhetic shellfish poisoning (DSP) (Haamer et al. 1990, Marcaillou-Lebaut et al. 1993, Blanco et al. 1995).

It seems apparent that, regardless of external factors, there was a progressive decrease in the detoxification rates as detoxification progressed. This decreasing trend is not constant: the rate is high during early detoxification and drops to almost zero after several weeks. When the total toxin concentration is examined instead of the corresponding rates, the evolution may be described as a detoxification in 2 phases: a fast one, which takes place during the early detoxification period, and a slow one, lasting from the end of the first phase to the end of detoxification. This type of 2-phase kinetics was found by Silvert \& Cembella (1995), Lassus et al. (1989), Bricelj et al. (1991) and White et al. (1993) for PSP toxins and by Marcaillou-Lebaut et al. (1993) for DSP toxins. It was also mentioned by Shumway (1990) as the usual detoxification behaviour. The progressive decrease in the detoxification rate indicates that the kinetics of this process only appears to have 2 phases, and that it is actually a continuous process. In our opinion this process has 2 components: the metabolic faecal losses and the elimination of the toxic cells and cell fragments from the digestive system. Hawkins \& Bayne (1984) and Hawkins et al. (1990) showed that metabolic faecal losses are relevant to mussels even at the level of the energetic balance of nutrition. These losses take place when the old cells of the digestive tubules break down and their constituents are released into the tubule lumen, to be discarded later with faeces. When this mechanism is combined with the high and unspecific binding of the PSP toxins by the cell membranes of the digestive gland (Louzao et al. 1992), it may cause the progressive decrease of the detoxification rate in accordance with the following description. During the process of intoxication, due to the high affinity of the membranes for PSP toxins, the older (and outer) cells should accumulate most of the toxin and only a small fraction of it should be transferred to the inner cells or to other tissues. When intoxication ceases, the first cells involved in the metabolic faecal losses are the outer (and the most toxic) ones, which transfer their toxicity to faeces and thus produce a strong decrease in toxicity. We think that this process may be supplemented by the elimination of the toxic phytoplankton cells and cell fragments from the digestive, as suggested by Silvert \& Cembella (1995) and Bricelj \& Cembella (1995). However, we do not consider the latter process to be the only mechanism involved in the rapid initial detoxification for 2 reasons: (1) only a small amount of toxin (relative to the initial amount) remains in the bivalves 
after the first few days of detoxification, which would seem unlikely if a structure-the digestive gland tubules - with a very high binding capacity for PSP is involved in the process; and (2) in some cases the number of cells needed to fill the entire digestive system contain fewer toxins than those released during the initial detoxification

Toxins are stored in varying quantities in different body tissues (Blogoslawski \& Stewart 1978, Beitler \& Liston 1990, Bricelj et al. 1990, 1991, Martin et al. 1990, Cembella et al. 1993, Cembella et al. 1994, Bricelj \& Cembella 1995, Cembella \& Shumway 1995), so we would expect to find a detoxification behaviour based on a number of compartments. It is obvious from our results that detoxification kinetics cannot be correctly described by means of a 1-compartment model. A 2 compartment model, however, seems to offer an adequate description of the detoxification process even when the actual situation is much more complex. Using the analysis of a toxicity time series including 2 PSP episodes, Silvert \& Cembella (1995) found that a 2-compartment model was sufficient to describe the toxin kinetics in another mussel (Mytilus edulis), which agrees with our findings.

Environmental conditions and body weight affected detoxification, but their importance varied in time. The regression estimation corresponding to each period suggests that the first period was the period most affected by environmental conditions and body weight. Salinity had a positive effect perhaps because of reduced filtration rates at low levels of this factor, as suggested by the decrease in body weight at the sampling points with the least salinity, or perhaps because it is inversely related to the fluorescence, which is an index of phytoplankton concentration, as shown in PCA. In this case, as in many others commonly found in nature, the precedence of factors has to be analysed with caution, given that in well-correlated pairs the factor measured with the greatest error (in this case fluorescence) is excluded from the regression by the process of backwards elimination.

Light transmission had a negative effect, which means that seston volume has a positive effect. There are a number of mechanisms that may help provide an explanation of this relationship and also of the possible effect of fluorescence. However, in our opinion, the most likely explanation is the effect of the seston volume on the digestive processes and, in particular, on metabolic faecal losses. The rates of both processes are strongly affected by the volume of seston ingested and therefore depends on the filtration/ingestion rate as well as on the seston concentration in volume.

Body weight seems to have varying effects during the different detoxification periods. In the 3 cases which showed a direct relationship (positive coefficient) the effect may be explained by the toxin dilution effect produced by the increase in biomass as was observed by Bricelj \& Cembella (1995). If the biomass increases and the toxin content remains unchanged, then the toxin/biomass ratio decreases. We cannot explain the inverse response found in an additional case, but this case was also the only one in which the loading of this variable on $\mathrm{PC} 2$, which is related to food availability. was opposite to that of fluorescence, indicating that body weight increase was not related to food resources. Therefore, the most likely explanation would be that this was the effect of a sampling error.

Temperature also presented positive and negative coefficients. In 2 out of 3 detoxification periods, the coefficients were positive as was the case in the last period, in which the regression coefficient for temperature was significant and the total explained variance was high. Our data are not consistent enough to be able to offer an unequivocal description of the effect of temperature throughout the entire detoxification period, although it seems to be more positive towards the end of the detoxification period.

An analysis of the effect of the inclusion of the environmental factors in the 1-or 2-compartment models shows that, in general, the fit is better when these factors are included than when they are not included, which would suggest that the variables considered have a real effect on the detoxification kinetics. Notwithstanding, the increase in the fit of the 2-compartment model with environmental factors was not substantially better than the fit of the 2-compartment model without environmental factors. Additionally when the main discrepancies are analysed, they exhibit a clear pattern. In the case of the 1-compartment model, the detoxification corresponding to all the bottom $(8 \mathrm{~m})$ sampling points was underestimated by the model, and in the 2-compartment model the detoxification at sampling point 2 is overestimated. Therefore, the discrepancies are most likely due to other variables not considered in this study rather than to an intrinsic lack of fit of the model including environmental variables. It also seems obvious that in some cases the inclusion of environmental variables may partially account for some variation that may also be attributed to the inclusion of the second compartment. This means that the quantification of the effect of the environment depends on the model assumed for the detoxification kinetics. Therefore, in order to determine the real extent of environmental control it would be necessary to measure the actual toxicities in each compartment.

Even though interconversions between PSP toxins have been observed in shellfish (Sullivan et al. 1993, Oshima 1995), no clear evidence was observed in our study. 


\section{LITERATURE CITED}

Aatvik B, Framstad K (1981) Assay and detoxification experiments with mytilotoxin in mussels (Mytilus edulis L.) from Nordassstraumen, Western Norway. Sarsia 66:143-146

Anderson DM, Sullivan JJ, Reguera B (1989) Paralytic shellfish poisoning in NW Spain: the toxicity of the dinoflagellate Gymnodinium catenatum. Toxicon 27(6):665-674

Bayne BL, Thompson RJ, Widdows J (1976a) Physiology I. In. Bayne BL (ed) Marine mussels: their ecology and physio. logy. Cambridge University Press, Cambridge, p 121-206

Bayne BL, Widdows J, Thompson RJ (1976b) Physiology II. In Bayne BL (ed) Marine mussels: their ecology and physiology. Cambridge University Press. Cambridge, p 207-260

Beitler MK, Liston J (1990) Uptake and tissue distribution of PSP toxins in butter clams. In: Granéli E, Sundström B, Edler L, Anderson DM (eds) Toxic marine phytoplankton. Elsevier, New York, p 257-262

Blanco J, Fernández M, Mariño J, Reguera B, Míquez A Maneiro J, Cacho E, Martinez A (1995) From Dinophysis spp. toxicity to DSP outbreaks: a preliminary model of toxin accumulation in mussels. In: Lassus P, Arzul G, Erard E, Gentien P, Marcaillou C (eds) Harmful marine algal blooms. Lavoisier, Intercept Ltd, Paris

Blogoslawski WJ, Stewart ME (1978) Paralytic shellfish poison in Spisula solidissima: anatomical location and ozone detoxification. Mar Biol 45:261-264

Bricelj VM, Cembella AD (1995) Fate of gonyautoxins in surfclams, Spisula solidissima, grazing upon toxigenic Alexandrium. In: Lassus $P_{1}$ Arzul G, Erard E, Gentien P, Marcaillou $C$ (eds) Harmful marine algal blooms. Lavoisier, Intercept Ltd, Paris, p 413-418

Bricelj VM, Lee JH, Cembella AD (1991) Influence of dinoflagellate cell toxicity on uptake and loss of paralytic shellfish toxins in the northern quahog Mercenaria mercenaria. Mar Ecol Prog Ser 74:33-46

Bricelj VM, Lee JH, Cembella AD, Anderson DM (1990) Uptake and kinetics of paralytic shellfish toxins from the dinoflagellate Alexandrium fundyense in the mussel Mytilus edulis. Mar Ecol Prog Ser 63:177-188

Cembella AD. Shumway SE (1995) Anatomical and spatiotemporal variation in PSP toxin composition in natural populations of the surfclam Spisula solidissima in the Gulf of Maine. In: Lassus P, Arzul G, Erard E, Gentien P, Marcaillou $C$ (eds) Harmful marine algal blooms. Lavoisier. Intercept Ltd, Paris, p 421-426

Cembella AD, Shumway SE, Larocque R (1994) Sequestering and putative biotransformation of paralytic shellfish toxins by the sea scallop Placopecten magellanicus: seasonal and spatial scales in natural populations. J Exp Mar Biol Ecol 180:1-22

Cembella AD, Shumway SE, Lewis NI (199.3) Anatomical distribution and spatio-temporal variation in paralytic shellfish toxin composition in two bivalve species from the Gulf of Maine. J Shellfish Res 12(2):389-403

Chebib $H$, Cembella AD, Anderson P (1993) Differential paralytic shellfish toxin accumulation and detoxification kinetics in transplanted populations of Mytilus edulis exposed to natural blooms of Alexandrium excavatum. In: Smayda TJ, Shimizu Y (eds) Toxic phytoplankton blooms at the sea. Elsevier, Amsterdam, p 383-388

Franca S, Alvito P, Sousa I, Mascarenhas V (1993) The dinoflagellate Gymnodinium catenatum isolated from the coast of Portugal: observations on development, toxicity and ultrastructure. In: Smayda TJ, Shimizu Y (eds) Toxic phytoplankton blooms at the sea. Elsevier, Amsterdam, p 383-388
Franco JM, Fernández P (1993) Separation of PSP toxins by RP-HPLC, with postcolum reaction and fluorometric detection. Chromatographia 35:613-620

Haamer J, Andersson PO, Lange S, Li XP, Edebo L. (1990) Effects of transplantation and reimmersion of mussels Mytilus edulis Linnaeus. 1758, on their contents of okadaic acid. J Shellfish Res 9:109-112

Hawkins AJS, Bayne BL (1984) Seasonal variation in the balance between physiological mechanisms of feeding and digestion in Mytilus edulis (Bivalvia:Mollusca). Mar Biol 82:233-240

Hawkins AJS, Bayne BL (1992) Physiological interrelations, and the regulation of production. In: Gossling $E$ (ed) The mussel Mytilus: ecology, physiology, genetics and culture. Elsevier, Amsterdam, p 171-222

Hawkins AJS, Navarro E, Iglesias JIP (1990) Comparative allometries of gut content, gut passage time and metabolic faecal loss in Mytilus edulis and Cerastoderma edule. Mar Biol 105:197-204

Lassus P, Fremy JM, Ledoux M, Bardouil M, Bohec M (1989) Patterns of experimental contamination by Protogonyaulax tamarensis in some French commercial shellfish. Toxicon 12:1313-1321

Louzao MC, López-Corona PP, Vieytes MR, Botana LM (1992) Unión de saxitoxina a receptores de fracciones celulares hepatopáncreas de mejillón Mytilus galloprovincialis Lmk. Cuad Área Ciencias Mariñas, Seminario de Estudos Galegos 6:65-72

Marcaillou-Lebaut C, Bardin B, Bardouil M, Bohec M, Le Dean L, Masselin P, Truquet P (1993) DSP depuration rates of mussels reared in a laboratory and an aquaculture pond. In: Smayda TJ, Shimizu Y (eds) Toxic phytoplankton blooms at the sea. Elsevier, Amsterdam, p 531-535

Martin JE, White AW, Sullivan JJ (1990) Anatomical distribution of paralytic shellfish toxins in soft-shell clams. In: Granéli E, Sundström B, Edler L, Anderson DM (eds) Toxic marine phytoplankton. Elsevier, New York, p 379-384

Oshima $Y$ (1995) Chemical and enzimatic transformation of PSP toxins in marine organisms. In: Lassus $P$, Arzul $G$, Erard E, Gentien P. Marcaillou C (eds) Harmful marine algal blooms. Lavoisier, Intercept Ltd, Paris, p 475-480

Oshima $\mathrm{Y}$, Itakura $\mathrm{H}$, Lee $\mathrm{KC}$, Yasumoto $T$, Blackburn $\mathrm{S}$. Hallegraeff G (1993) Toxin production by the dinoflagellate Gymnodinium catenatum. In: Smayda TJ, Shimizu Y (eds) Toxic phytoplankton blooms at the sea. Elsevier, Amsterdam, p $907-912$

Sampayo MA, Alvito P. Franca S, Sousa I (1990) Dinophysis spp. toxicity and relation to accompanying species. In: Granéli E, Sundström B, Edler L, Anderson DMM (eds) Toxic marine phytoplankton. Elsevier, New York, p 215-220

Shumway SE (1990) A review of the effects of algal blooms on shellfish and aquaculture. J World Aquacult Soc 21(2): 65-104

Shumway SE, Cembella AD (1993) The impact of toxic algae on scallop culture and fisheries. Rev Fish Aquat Sci 1 $121-150$

Shumway SE, Sherman-Caswell S, Hurst JW (1988) Paralytic shellfish poisoning in Maine: monitoring a monster J Shellfish Res 7(4):643-652

Silvert W. Cembella AD (1995) Dynamic modelling of phycotoxin kinetics in the blue mussel, Mytilus edulis, with implications for other marine invertebrates. Can J Fish Aquat Sci 52:521-531

Silvert W, Subba-Rao DV (1992) Dynamic model of the flux of domoic acid, a neurotoxin, through a Mytilus edulis population. Can J Fish Aquat Sci 49:400-405 
Sommer H, Meyer KF (1937) Paralytic shellfish poisoning Arch Pathol 24:560-598

Sullivan JJ, Iwaoka WT, Liston J (1993) Enzymatic transformation of PSP toxins in the littleneck clam (Protothaca staminea). J Biochem Biophys Res Comm 114:465-472

White AW, Nassif J, Shumway SE, Whittaker DK (1993) Recent occurrence of paralytic shellfish toxins in offshore

Editorial responsibility: Otto Kinne (Editor)

Oldendorf/Luhe, Germany shellfish in the Northeastern United States. In: Smayda TJ, Shimizu Y (eds) Toxic phytoplankton blooms at the sea. Eisevier, Amsterdam, p 435-440

Wohlgeschaffen GD, Mann KH, Subba Rao DV, Pocklington R (1992) Dynamics of the phycotoxin domoic acid: accumulation and excretion in two commercially important bivalves. J Appl Phycol 4:297-310

Submitted: March 18, 1997; Accepted: August 25, 1997 Proofs received from author(s): October 17, 1997 